To the Editors:

\title{
'Kuppi' classes versus the assessed curriculum
}

Ceylon Medical Journal 2011; 56: 85

I read with interest the point of view on 'hidden and informal curricula in medical schools....' in your previous issue [1]. I wish to congratulate the author on this enlightening article. I, however, have two comments.

First, although in the past there was no formal teaching of professionalism, interpersonal skills, and ethics in medical schools, I wish to note that most medical schools now have formal teaching programmes covering the above topics. Second, I wish to shed more light on one of the main claims in this article: "There is an ongoing conflict between the formal curriculum and the informal/hidden curriculum with criticism and resistance against 'kuppi' classes."

The criticisms against 'kuppi' classes that the author states, though true, are mostly socio-political in nature. The real 'educational' criticism, however, is that 'kuppi' classes provide only examination-centred learning; i.e. 'kuppi' classes only coach students to pass examinations.

This brings us to another curriculum that I wish to add to the formal, informal, and hidden curricula that the author mentions. That is the 'assessed' curriculum. Classical medical education literature prescribes that the planned (formal), taught (formal and informal), learned (formal, informal, and hidden), and assessed curricula should be in perfect synchrony. In educational jargon, this is called 'constructive alignment' [2]. It is in this light that we should analyse the above, perhaps the only, educational criticism against 'kuppi' classes.

We should be worried about 'kuppi' classes being examination-centred (they in fact are), only if our planned and taught curricula are significantly different to our assessed curriculum. If not, we should hail 'kuppi' classes as a perfect example of much vaunted 'peer assisted learning' [3].

So, if medical schools want to convert 'kuppi' classes to educationally sound peer assisted learning, then they need to get their examinations right. If a given examination assesses a representative sample of all that the students should have learned, then I see no problem in 'kuppi' classes being examination-centred.

In short, while not for a moment playing down the importance of the informal and hidden curricula, it is clear that the impact of the assessed curriculum is far greater than the impact of all other forms of curriculum. Medical schools need to realise this home truth sooner than later. Thus, the remedy lies in not scapegoating 'kuppi' classes or any such informal/hidden mechanism, but in developing educationally sound assessment.

\section{References}

1. Kommalage M. Hidden and informal curricula in medical schools: impact on the medical profession in Sri Lanka. Ceylon Medical Journal 2011; 56: 29-30.

2. Biggs J. Teaching for Quality Learning at University. Buckingham: SRHE and Open University Press 1999.

3. Boud D, Cohen R, Sampson J. Peer learning and assessment. Assessment and Evaluation in Higher Education 1999: 24: 413-26.

\section{G Ponnamperuma ${ }^{1}$}

${ }^{1}$ Department of Medical Education, Faculty of Medicine, University of Colombo, Sri Lanka.

Correspondence: GP, e-mail: <gomindap@hotmail.com>. 